\title{
Diversity of Meq gene from clinical Marek's disease virus infection in Saudi Arabia
}

\author{
Mahmoud H. A. Mohamed ${ }^{1,2}$, Ibrahim M. El-Sabagh ${ }^{3,4}$, Malik A. Al-Habeeb ${ }^{5}$ and Yousef M. Al-Hammady
}

1. Department of Clinical Studies, College of Veterinary Medicine, King Faisal University, Al-Hufof, 31982, Saudi Arabia;

2. Department of Avian and Rabbit Medicine, Faculty of Veterinary Medicine, Zagazig University, 44519, Zagazig, Egypt; 3. Central Biotechnology Laboratory, College of Veterinary Medicine, King Faisal University, Al-Hufof, 31982, Saudi

Arabia; 4. Department of Virology, Faculty of Veterinary Medicine, Cairo University, 12211, Giza, Egypt; 5. Excutive Department of Risk Assessment, Saudi Food and Drug Authority, Saudi Arabia; 6. Central Veterinary Laboratory, Riyadh, Saudi Arabia.

Corresponding author: Ibrahim M. El-Sabagh, e-mail: ibrahimelsabagh@yahoo.com, MHAM: mahmoudhassanain@yahoo.com, MAA: mxm0063@hotmail.com,YMA: ymh_82_01@hotmail.com Received: 27-01-2016, Accepted: 22-04-2016, Published online: 10-06-2016

doi: 10.14202/vetworld.2016.572-578Howtocitethisarticle: MohamedMHA, El-Sabagh IM, Al-Habeeb MA, Al-Hammady YM (2016) Diversity of Meq gene from clinical Marek's disease virus infection in Saudi Arabia, Veterinary World, 9(6): 572-578.

\section{Abstract}

Aim: The aim of this study was to demonstrate the genomic features of Meq gene of Marek's disease virus (MDV) recently circulating in Saudi Arabia (SA).

Materials and Methods: Two poultry flocks suffering from mortalities and visceral tumors were presented to the Veterinary Teaching Hospital, King Faisal University, SA. Subjected to different diagnostic procedures: Case history, clinical signs, and necropsy as well as polymerase chain reaction followed by $\mathrm{Meq}$ gene sequence analysis.

Results: Case history, clinical signs, and necropsy were suggestive of MDV infection. The Meq gene was successfully detected in liver and spleen of infected chickens. A $1062 \mathrm{bp}$ band including the native Meq ORF in addition to a $939 \mathrm{bp}$ of $S-M e q$ (short isoform of Meq) were amplified from Saudi 01-13 and Saudi 02-13, respectively. The nucleotide and deduced amino acids sequences of the amplified $M e q$ genes of both Saudi isolates showed distinct polymorphism when compared with the standard USA virulent isolates Md5 and GA. The sequence analysis of the $S$-Meq gene showed a 123 bp deletion representing 41 amino acids between two proline-rich areas without any frameshift. The Meq gene encoded four repeats of proline-rich repeats (PRRs sequences), whereas the $S$-Meq contains only two PRRs. Interestingly, the phylogenetic analysis revealed that both of SA MDV isolates are closely related to the MDV strains from Poland.

Conclusion: The two MDV isolates contain several nucleotide polymorphisms resulting in distinct amino acid substitutions. It is suggested that migratory and wild birds, as well as world trading of poultry and its by-products, have a great contribution in the transmission of MDVs overseas.

Keywords: deletion, Marek's disease virus, Meq gene sequence, phylogenic analysis, Saudi Arabia.

\section{Introduction}

Marek's disease (MD) is lymphoproliferative disease of chickens caused by the highly infectious cell-associated alphaherpesvirus MD virus serotype 1 (MDV1) or Gallid herpesvirus 2 and induces malignant lymphomas in chickens [1]. Currently, MD has been effectively controlled using the vaccines along with good management practice, and major losses to the poultry industry as a result of the disease have largely been averted [2-4].

The MDV genome of Md5 strain is about 177,874 bp linear dsDNA; it is predicted to encode 103 proteins [5]. The genetic basis and molecular mechanisms underlying viral virulence and oncogenicity remain poorly understood. The search for viral

Copyright: Mohamed, et al. Open Access. This article is distributed under the terms of the Creative Commons Attribution 4.0 International License (http://creativecommons.org/licenses/ by/4.0/), which permits unrestricted use, distribution, and reproduction in any medium, provided you give appropriate credit to the original author(s) and the source, provide a link to the Creative Commons license, and indicate if changes were made. The Creative Commons Public Domain Dedication waiver (http:// creativecommons.org/publicdomain/zero/1.0/) applies to the data made available in this article, unless otherwise stated. factors related to oncogenicity identified the viral genes encoding proteins involved in T-cell transformation $(\mathrm{Meq})$ and others with potential involvement in tumorigenicity, viral virulence, and host range (pp24, pp38, viral interleukin 8) [6,7].

The Meq gene encodes a 339-amino acid protein with an N-terminal basic region leucine zipper (bZIP) domain and a C-terminal transactivation domain [8]. The bZIP domain, similar to that of the Jun/Fos family of oncoprotein, consists of two stretches of basic residues basic regions 1 and 2 (BR1 and BR2) and a leucine zipper [8]. The transactivation domain is characterized by 2.5 proline-rich repeats (PRRs), which contain several SH3-binding motifs [8]. Several studies showed that the attenuated MDV shows some deletions in the BamHI-D and $\mathrm{H}$ fragments and has an inserted repeat sequence in the unique long region (UL) of the genome compared to the parent [9]. On the other hand, attenuated strains of MDV1 are not oncogenic although no structural or transcriptional changes have been reported concerning Meq gene [10]. Several reports suggested that the number of PRRs and point mutations in PPPP 
stretches might provide an indication of the isolate pathogenicity $[4,11]$. As a requirement for the disease control in Saudi Arabia (SA), vaccination with a cell associated modified live CVI988 and herpesvirus of turkey (HVT) strain FC 126 are frequently used in broiler and layers chickens at 1-day old. The vaccination failure and inability of the vaccine to protect chickens against overt clinical signs following field infection may be due to increasing in the virulence of the virus or early exposure [12].

In this study, we aimed to characterize MDVs circulated in the eastern region of SA using polymerase chain reaction (PCR) and genomic sequencing and detect the diversity of the $\mathrm{Meq}$ gene structure between two oncogenic MDVs from field cases.

\section{Materials and Methods}

\section{Ethical approval}

This study was carried out after the necessary permission of Institutional Animal Ethics committee, King Faisal University, Saudi Arabia.

\section{Case history and clinical specimens}

12-15 weeks old layer chickens from two farms in the eastern region, SA, vaccinated with commercial MDV vaccines (contains cell associated modified live Marek's Rispens CVI988 strain virus and HVT strain FC 126), were represented to the Avian Clinic, Veterinary Teaching Hospital, King Faisal University, Al-Hassa, SA. Birds showing high mortality (10\%) with signs of depression and general weakness. Birds subjected to routine postmortem examination. Samples of liver, spleen, kidneys, and proventriculus were collected aseptically and subjected to molecular detection and characterization of MDV in the Central Biotechnology Laboratory.

\section{DNA extraction}

Total DNA was extracted from up to $25 \mathrm{mg}$ spleen samples as well as commercial live attenuated MDV as a positive control using DNeasy Blood and Tissue Kit (QIAGEN, USA). After complete lysis of the specimens by ATL buffer and proteinase K, absolute ethanol was added then the mixture was transferred to a spin column according to manufacturer's protocol. Purified DNAs were recovered in $150 \mu \mathrm{AE}$ buffer and stored at $-20^{\circ} \mathrm{C}$ for further testing.

\section{Detection of the Meq oncoprotein gene}

The extracted DNAs were screened for presence of MDV using HotStartTaq ${ }^{\circledR}$ Plus Master Mix Kit (QIAGEN, USA). $2 \mu 1$ sample of each purified genomic DNAs was amplified in $20 \mu \mathrm{l}$ of the final volume of a $2 \mathrm{X}$ HotStartTaq Plus Master Mix containing $1.5 \mathrm{mM} \mathrm{MgCl}, 200 \mu \mathrm{M}$ of each dNTP, 1 unit HotStartTaq Plus DNA polymerase, and $10 \mu \mathrm{M}$ of each forward (F:GCACTCTAGAGTGTA AAGAGATGTC TCAG) and reverse (R:TAACTCG AGGAGAAGAAACATGG GGCATAG) primers [13]. Thermo-cycling conditions were enzyme activation and initial denaturation at $95^{\circ} \mathrm{C}$ for $5 \mathrm{~min}$ followed by
35 cycles of $94^{\circ} \mathrm{C}$ for $30 \mathrm{~s}, 55^{\circ} \mathrm{C}$ for $30 \mathrm{~s}$, and $72^{\circ} \mathrm{C}$ for $30 \mathrm{~s}$ and a final extension step at $72^{\circ} \mathrm{C}$ for $10 \mathrm{~min}$. The amplified PCR products were electrophoresed in $1.5 \%$ agarose gel stained with ethidium bromide and documented using ultraviolet gel documentation system (BIORAD).

\section{Sequencing and construction of phylogenetic tree}

$M e q$ gene specific bands were excised from the agarose gel, purified using Montàge DNA gel extraction kit (Millipore, USA) and sequenced in an automated ABI 3730 DNA sequencer (Applied Biosystems, USA). The obtained sequence was aligned by the Clustal W method. The obtained nucleotide sequences were compared with MDV sequences available in Genbank by BLAST web tool of the Genbank (Table-1). A phylogenetic tree was constructed using MEGA version 5.20 software.

\section{Genbank accession number}

The obtained Meq gene sequences of the detected MDV were submitted to the GenBank database with the accession number (Saudi 01-13; KJ949617 and Saudi 02-13; KJ949618).

\section{Results}

\section{Clinical examination}

Birds necropsy and morphological observations of the visceral organs revealed enlarged liver with

Table-1: MDV reference strains used in construction the phylogenetic tree.

\begin{tabular}{llll}
\hline $\begin{array}{l}\text { Accession } \\
\text { No. }\end{array}$ & Country & Name & Reference \\
\hline HM991861 & China & MDV/BY/China & {$[30]$} \\
HQ638151 & China & MDV/TQ20/CH & {$[31]$} \\
EF546430 & China & MDV/GXY2/CH & Unpublished \\
HQ658624 & China & MDV/HLJ/07/II & {$[7]$} \\
HQ658619 & China & MDV/LN/08/V & {$[7]$} \\
HQ658627 & China & MDV/HLJ/06/I & {$[7]$} \\
AY362712 & USA & MDV/617A & {$[21]$} \\
KJ464784 & Poland & MDV/12_08 LORF7 & Unpublished \\
KJ464771 & Poland & MDV/5_06 LORF7 & Unpublished \\
HQ204815 & Poland & MDV/73_08_PL & Unpublished \\
AY362725 & USA & MDV/648A & {$[21]$} \\
AF243438 & USA & MDV/Md5 & {$[5]$} \\
HM749326 & India & MDV/tn-n3 & Unpublished \\
AB638844 & Japan & MDV/Tokachi-s1 & {$[28]$} \\
KC243264 & Iraq & MDV/10A & {$[11]$} \\
KC243266 & Iraq & MDV/51C & {$[11]$} \\
KC243266 & Iraq & MDV/95E & {$[11]$} \\
EF523775 & Australia & MDV/Woodsland1 & Unpublished \\
EF523775 & Australia & MDV/FT158 & Unpublished \\
AF493558 & China & MDV/648A & Unpublished \\
AF493555 & Netherland & MDV/CVI988 & Unpublished \\
HF546085 & China & MDV/HNGS201 & {$[12]$} \\
KC161221 & Egypt & MDV/Egypt_5 & {$[32]$} \\
EF523390 & USA & MDV/RB-1B & Unpublished \\
AF147806 & USA & MDV/GA & {$[22]$} \\
EF523774 & Australia & MDV/MPF75 & Unpublished \\
JX467678 & Egypt & MDV/Egypt_1 & {$[32]$} \\
JN808272 & India & MDV/ABT/HSR/5253 Unpublished \\
JN808280 & India & MDV/ABT/HSR/7158 Unpublished \\
KJ464769 & Poland & Wroclaw_06 LORF7 & Unpublished \\
\hline MDV=Marek's & &
\end{tabular}

MDV=Marek's disease virus 
rounded edges multiple grayish tumors and the spleen were enlarged with grayish nodules.

\section{Molecular detection of Meq gene}

PCR analysis of $M e q$ gene ORF specific for MDV serotypes 1 was done to detect MVD in DNA of tested samples. A $1062 \mathrm{bp}$ fragment was detected in sample 1, whereas in sample 2, a smaller fragment was observed (939 bp).

\section{Sequence and phylogenetic analysis of different Meq gene fragments}

Nucleotide gene sequence of the $\mathrm{Meq}$ gene ORF detected in Saudi 01-13 was 1062 bp encoding for a polypeptide of 339 amino acids, whereas the $S-M e q$ ORF of Saudi 02-13 (939 bp) showed deletion of about 123 bp between the nucleotides 538 and 660 of the ORF. The deleted area encoding for a polypeptide 41 amino acids without frameshift (Figures-1 and 2). The deletion site was identified between two PRR regions in C-terminal proline-rich domain. Nucleotide and deduced amino acid sequences of the MDV isolates from SA were highly conserved when compared to MDV strains worldwide (CVI988/NLT, GA/ USA, Md5/USA, 12 08LO-RF7/PL, and RB-1B/ USA). Three amino acid substitutions: Asp.80Tyr., Cys.110Ser., and Pro.218Ser. were identified in the Meq of MDVs isolated from SA and MDV strain from Poland (12_08LO-RF7/POL), in addition, eight amino acids substitutions were identified among the Saudi strains and MDVs from Iraq (Table-2).

\section{Phylogenetic analysis}

The obtained nucleotide sequences of $\mathrm{Meq}$ gene (Saudi 01-13 and Saudi 02-13) were compared with those of 30 references MDVs summarized in Table-1 for homology analysis using MEGA version 5.2. These 30 reference MDVs representing different regions all over the world. The Saudi 01-13 and Saudi 02-13 had the highest nucleotide homology $(99.8 \%$ and 99.6\%) with 12 08LORF7/PL, respectively (Figure-3). Comparing the antigenic peaks (index) of both Saudi MDVs, Iraq 95 and 12_08/LORF7/POL, the data showed that they are quite similar although the Saudi 02-13 and Iraq 95 showing a deletion of 123 nucleotide representing 41 amino acid which support the hypothesis that the deletion did not cause frame shift (Figure-4).

\section{Discussion}

In the last 40 years, the incidence and interest to MDV has been increasing because of the intensive use of vaccination to control the disease [14]. The virus isolation, genomic sequencing as well as monitoring the oncogenic genes changes are played an important role in the prevention and control of MDV infection in chickens [15]. The polymorphism of Meq gene amino

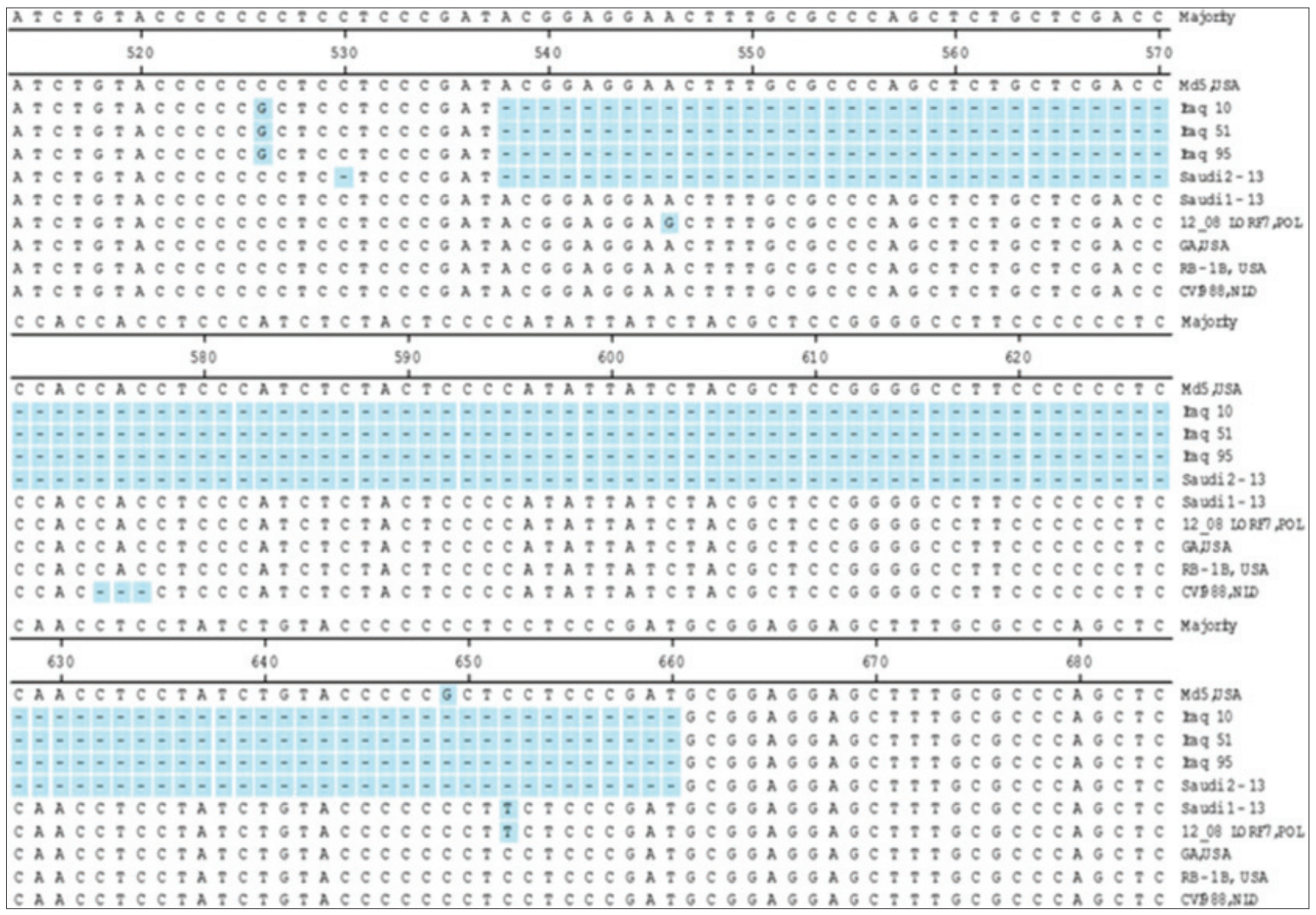

Figure-1: Alignment of $\mathrm{Meq}$ gene sequences. The nucleotides alignment of Meq genes from the strains listed at the right. Unmatched sequences represented by dashes (-). Deletion of nucleotides (538-660) in Saudi 02-13 without frameshifting. 
Table-2: Amino acid substitution of Meq gene protein.

\begin{tabular}{|c|c|c|c|c|c|c|c|c|c|c|c|c|c|}
\hline \multirow[t]{3}{*}{ Strain/country } & \multicolumn{13}{|c|}{ Amino acids position/substitutions } \\
\hline & \multicolumn{3}{|c|}{ Basic region } & \multirow{2}{*}{$\frac{\text { Leu Zip }}{110}$} & \multicolumn{9}{|c|}{ Transactivation domain } \\
\hline & 71 & 77 & 80 & & 141 & 168 & 194 & 200 & 217 & 218 & 283 & 320 & 328 \\
\hline CVI988/NLD & $\mathrm{S}$ & $E$ & $\mathrm{D}$ & $\mathrm{C}$ & $\mathrm{H}$ & $\mathrm{S}$ & - & I & $P$ & $P$ & A & I & $\mathrm{S}$ \\
\hline GA/USA & $A$ & $\mathrm{~K}$ & $\mathrm{D}$ & $\mathrm{C}$ & $\mathrm{H}$ & $\mathrm{S}$ & $\mathrm{P}$ & I & $\mathrm{P}$ & $\mathrm{P}$ & $A$ & I & $\mathrm{S}$ \\
\hline Md5/USA & A & $\mathrm{K}$ & D & C & $\mathrm{H}$ & $\mathrm{S}$ & $\mathrm{P}$ & I & A & $\mathrm{P}$ & V & $\mathrm{T}$ & $\mathrm{S}$ \\
\hline Saudi 01-13 & A & $\mathrm{E}$ & $\mathrm{Y}$ & $\mathrm{S}$ & $\mathrm{P}$ & $\mathrm{S}$ & $\mathrm{P}$ & I & $\mathrm{P}$ & $\mathrm{S}$ & A & I & $\mathrm{S}$ \\
\hline Saudi $02-13^{*}$ & $A$ & $\mathrm{E}$ & $\mathrm{Y}$ & $\mathrm{S}$ & $\mathrm{P}$ & $\mathrm{S}$ & - & - & - & $\mathrm{S}$ & $A$ & I & $\mathrm{S}$ \\
\hline 12_08/LORF7/POL & $A$ & $E$ & $\mathrm{Y}$ & $\mathrm{S}$ & $\mathrm{P}$ & $\mathrm{S}$ & $\mathrm{P}$ & I & $P$ & $\mathrm{~S}$ & $A$ & I & $\mathrm{L}$ \\
\hline RB-1B/USA & A & $\mathrm{K}$ & D & C & $\mathrm{H}$ & $\mathrm{S}$ & $\mathrm{P}$ & I & $\mathrm{P}$ & $\mathrm{P}$ & A & I & $\mathrm{S}$ \\
\hline Iraq $10 *$ & $\mathrm{~S}$ & $\mathrm{E}$ & D & C & $\mathrm{H}$ & $\mathrm{P}$ & - & - & A & $\mathrm{P}$ & A & I & $\mathrm{S}$ \\
\hline Iraq $51 *$ & $\mathrm{~S}$ & $E$ & $\mathrm{D}$ & C & $\mathrm{H}$ & $\mathrm{S}$ & - & - & $A$ & $P$ & $A$ & I & $\mathrm{S}$ \\
\hline Iraq 95* & $\mathrm{S}$ & $E$ & $\mathrm{D}$ & $\mathrm{C}$ & $\mathrm{H}$ & $\mathrm{S}$ & - & - & $A$ & $P$ & $A$ & I & $\mathrm{S}$ \\
\hline
\end{tabular}

*MDVs isolates with S-Meq. MDV=Marek's disease virus

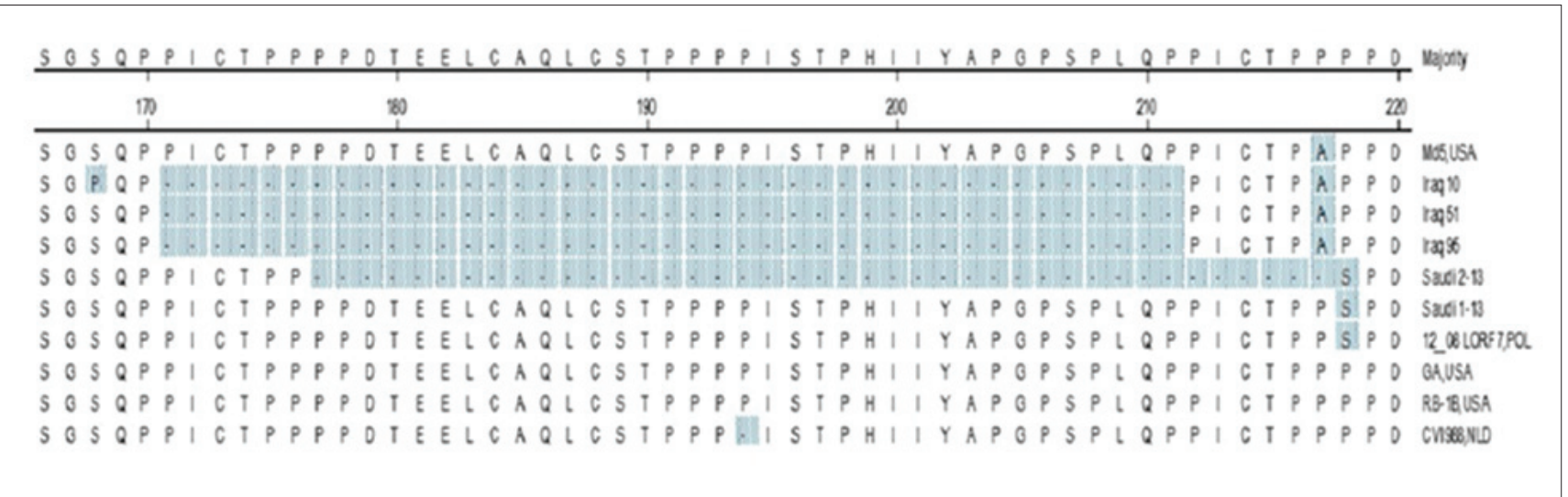

Figure-2: Alignment of Meq gene amino acids sequences. The amino acid alignment of Meq genes from the strains listed at the right. Unmatched sequences represented by dashes (-). Deletion of amino acids (177-217) in Saudi 02-13 without frameshifting.

acids sequences, as well as point mutations, was found to be correlated to MDV1 virulence [16-18]. The Meq gene product is a transcription factor with $\mathrm{N}$-terminal bZIP proteins homologs to Jun/Fos oncoproteins [6].

$\mathrm{Meq}$ can interact with itself and cellular proteins such as $\mathrm{p} 53$ and C-terminal binding protein and can contribute to cellular oncogenesis [19]. Analysis of MDV genome showed several changes including the expansion of the $132 \mathrm{bp}$ direct repeats located in the internal repeat regions flanking the long unique region $[20,21]$. On the other hand, differences in the $M e q$ gene between oncogenic and non-oncogenic MDV1 have been reported as a result of 177 or $180 \mathrm{bp}$ insertion in the Meq gene that may postulate as a cause of biological changes results in attenuation of the MDV1 oncogenic strains [16,18,22].

In this study, the main complaint of the owners of two layer flocks aged 12 and 15 weeks old chickens were uneven growth and about 10\% mortalities. Following necropsy, there have been found enlargement of the liver and spleen with grayish, yellowish nodules. No lesions were seen on the skin as well as nervous tissues. In addition, gross lesions associated with emaciation were recorded as previously reported [23-26]. Lesions were suggestive for MD [27]. For further diagnosis, samples were tested using conventional PCR [13]. PCR was positive for $\mathrm{Meq}$ gene of MDVs. Unlikely, predicted the size of the PCR products from Saudi 01-13 and Saudi 02-13 were different. The reason why the two bands are different may be due to genetic diversity (deletion or insertion) of the amplified $\mathrm{Meq}$ gene as reported by Chang et al. [18] and Lee et al. [22].

The $M e q$ gene of both MDV isolates was compared with five standard MDVs, deletion of $123 \mathrm{bp}$ in the Meq ORF (538-660) between two PRRs in the C-terminal proline-rich domain was detected in Saudi 02-13. The deletion did not cause any frameshift in the $M e q$ gene ORF. Wajid et al. [11] reported a $123 \mathrm{bp}$ deletion in $\mathrm{Meq}$ gene from Iraq. Surprisingly, the deletion in the $\mathrm{Meq}$ gene of Iraq strains starts from the same nucleotide positions as Saudi isolates (Figure-1). Whereas, on the corresponding amino acid sequence, the deletion occurred between 2 proline residues ${ }^{170} \mathrm{P} \downarrow \mathrm{P}^{171}$ while in Saudi isolates the deletion was in PRR ${ }^{175} \mathrm{PP} \downarrow \mathrm{PP}^{178}$ this may be due to the missed nucleotide at position 530 in the Saudi 02-13 (Figure-2). Previous studies showed that the $\mathrm{Meq}$ gene is considered the most important molecule in MDV oncogenicity and among the notable finding related to the virulence was distinct diversity and point mutation in the $\mathrm{Meq}$ proteins [4,18,21-28]. Structural changes in 


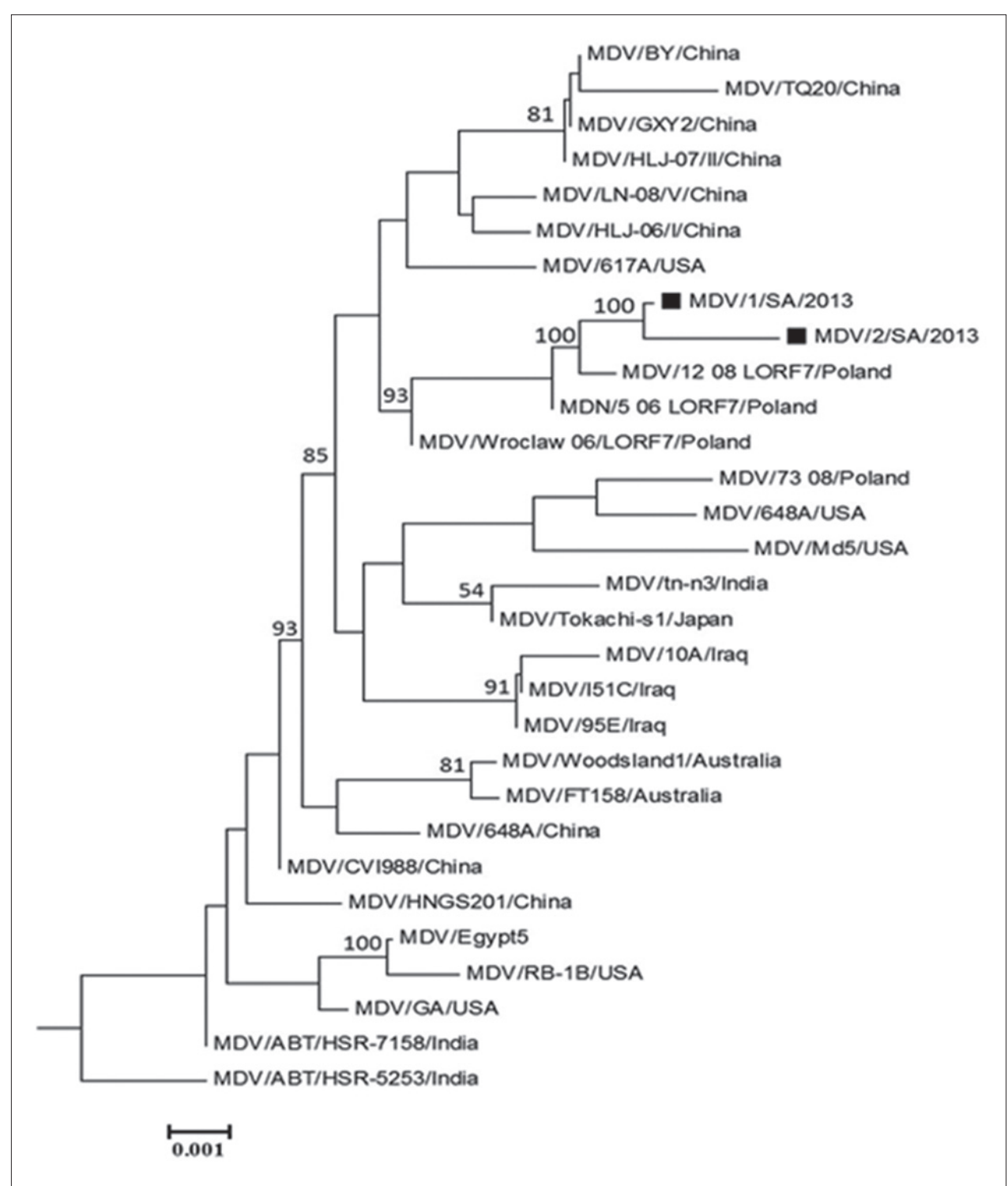

Figure-3: Phylogenetic analysis on Meq gene sequences of 2 Saudi Arabian isolates and other 30 references Marek's disease virus. The phylogenetic tree was constructed using the MEGA version 5.0 by the neighbor-joining method with 1000 bootstrap replicates. Black squares indicate the two isolates from Saudi Arabia.

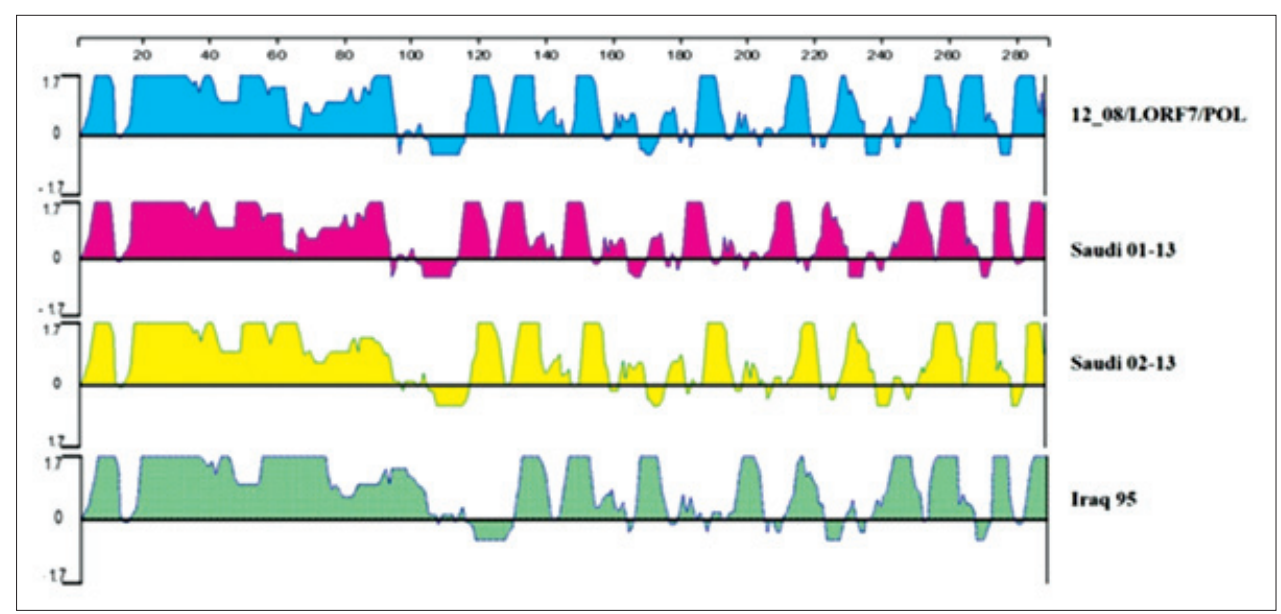

Figure-4: Antigenic index according to Jameson-Wolf for both Saudi Marek's disease virus, Iraq 95 and 12_08/LORF7/POL. Using Protean analysis DNASTAR Software Package.

the MDV genome were previously reported including 200-bp deletion in BamHI/L of MDV strain MD11 and $400 \mathrm{bp}$ deletion in the BamHI-A region of MDV strain
CVI988 [29]. On the hand, insertion of 177 or $180 \mathrm{bp}$ in the $\mathrm{Meq}$ gene of CVI988 was reported and does not cause any frameshift in $\mathrm{Meq}$ gene ORF that may result 
in attenuation $[21,22]$. The number of PPPP motif in the PRRs was 4 in the Saudi 01-13 and 2 in the Saudi 02-13; this previously reported as a virulence dependent factor the low number of PRRs is correlated to the high in virulence $[4,11]$. Both Saudi isolates had point mutations that interrupted extensions of four proline at position $3{ }^{216} \mathrm{PPPP}^{219}$ to ${ }^{216} \mathrm{PPSP}^{219}$ which are a unique substitution in Saudi isolates and 12_08LORF7/POL. Comparison of $\mathrm{Meq}$ gene sequence of the studied strains with 30 reference MDV1 strains revealed that the SA MDV strains clustered with the MDV strains from Europe (12 08LORF7/POL) that may be contributed to the importation of poultry and/or poultry by-products from European countries or due to movement of birds during migration.

\section{Conclusion}

For our knowledge, this is the first comprehensive study describe the incidence of MDV in SA. Both of the detected MDV strains causing lymphomas in layer chickens. Based on the clinical picture and the genomic sequencing both of the MDV isolates found to have characteristics of virulent MDVs although the Saudi 02-13 showed deletion of $123 \mathrm{bp}$ without causing any frameshift. The antigenic index of Saudi MDVs and certain regional and international isolates were quite similar. In Saudi 02-13, the amino acid deletion started at position 177 is due to the short isoform of Meq. More concern should be given to the imported poultry and poultry by-products, migratory birds as well as vaccination process to control the MDV infection.

\section{Authors' Contributions}

MHM and IME: Study design, PCR, Genomic analysis and prepared the manuscript. MA and YA: Collected samples. All authors read and approved the final manuscript.

\section{Acknowledgments}

The authors are highly thankful to Collage of Veterinary Medicine, King Faisal University, Saudi Arabia, for providing necessary support to carry out the work by the Scientific Research Deanship [Project \# 150047].

\section{Competing Interests}

The authors declare that they have no competing interests.

\section{References}

1. Calnek, B.W. and Witter, R.L. (1991) Marek's disease. In: Calnek, B.W., editor. Diseases of Poultry. $10^{\text {th }}$ ed. Iowa State University Press, Ames, Iowa, p369-413.

2. Chang, S., Dunn, J.R., Heidari, M., Lee, L.F., Ernst, C.W., Song, J. and Zhang, J. (2012) Vaccine by chicken line interaction alters the protective efficacy against challenge with a very virulent plus strain of Marek's disease virus in White Leghorn chickens. World J. Vac., 2: 1-11.

3. Gimeno, I.M., Witter, R.L., Cortes, A.L., Reddy, S.M. and Pandiri, A.R. (2012) Standardization of a model to study revaccination against Marek's disease under laboratory conditions. Avian Pathol., 41: 59-68.

4. Renz, K., Cooke, J., Cheetham, B., Hussain, Z., Islam, A., Tannock, G. and Brown, S. (2012) Pathotyping of Australian isolates of Mareks disease virus and association of pathogenicity with MEQ gene polymorphism. Avian Pathol., 41: 161-176.

5. Tulman, E.R., Afonso, C.L., Lu, Z., Zsak, L.D., Rock, L. and Kutish, G.F. (2000) The genome of a very virulent Marek's disease virus. J. Virol., 74(17): 7980-7988.

6. Jones, D., Lee, L., Liu, J.L., Kung, H.J. and Tillotson, J.K. (1992) Marek's disease virus encodes a basic-leucine zipper gene resembling the fos/jun oncogenes that is highly expressed in lymphoblastoid tumors. Proc. Natl. Acad. Sci. U.S.A., 89: 4042-4046.

7. Zhang, Y.P., Liu, C.J., Zhang, F., Shi, W. and Li, J. (2011) Sequence analysis of the MEQ gene in the predominant Marek's disease virus strains isolated in China during 20062008. Virus Genes., 43: 353-357.

8. Liu, J.L. and Kung, H.J. (2000) Marek's disease herpesvirus transforming protein MEQ: A C-Jun analogue with an alternative life style. Virus Genes. 21: 51-64.

9. Peng, Q., Zeng, M., Bhuiyan, Z.A., Ubukata, E., Tanaka, A., Nonoyama, M. and Shirazi, Y. (1995) Isolation and characterization of Marek's disease virus (MDV) cDNAs mapping to the BamHI-I2, BamHI-Q2, and BamHI-L fragments of the MDV genome from lymphoblastoid cells transformed and persistently infected with MDV. Virology, 213: 590-599.

10. Sung, H.W. (2002) Recent increase of Marek's disease in Korea related to the virulence increase of the virus. Avian Dis., 46: 517-524.

11. Wajid, S.J., Katz,M.E., Renz,K.G. andWalkden-Brown, S.W. (2013) Prevalence of Marek's disease virus in different chicken populations in Iraq and indicative virulence based on sequence variation in the EcoRI-Q (MEQ) gene. Avian Dis., 57: 562-568.

12. Yu, Z.H., Teng, M., Luo, J., Wang, X.W., Ding, K., Yu, L.L., Su, J.W., Chi, J.Q., Zhao, P., Hu, B., Zhang, G.P. and Liu, J.X. (2013) Molecular characteristics and evolutionary analysis of field Marek's disease virus prevalent in vaccinated chicken flocks in recent years in China. Virus Genes., 47(2): 282-291.

13. Król, K., Samorek-Salmonowicz, E., Kozdruń, W. and Woźniakowski, G. (2007) Duplex PCR assay for detection and differentiation of pathogenic and vaccine strains serotype 1. Bull. Vet. Inst. Pulawy., 51: 331-335.

14. Witter, R.L., Calnek, B.W., Buscagli, C., Gimeno, I.M. and Schat, K.A. (2005) Classification of Marek's disease viruses according to pathotype: Philosophy and methodology. Avian Pathol., 34: 75-90.

15. Tan, J., Cooke, J., Clarke, N. and Tannock, G.A. (2008) Optimization of methods for the isolation of Marek's disease viruses in primary chicken cell cultures. J. Virol. Methods, 147: 312-318.

16. Schat, K.A. (1987) Marek's disease: A model for protection against herpesvirus induced tumours. Cancer Surv., 6: 1-37.

17. Liu, J.L., Ye, Y., Lee, L.F. and Kung, H.J. (1998) Transforming potential of the herpesvirus oncoprotein MEQ: Morphological transformation, serum-independent growth, and inhibition of apoptosis. J. Virol., 72: 388-395.

18. Chang, K.S., Ohashi, K. and Onuma, M. (2002) Diversity (polymorphism) of the MEQ gene in the attenuated Marek's disease virus (MDV) serotype one an MDV-transformed cell lines. J. Vet. Med. Sci., 64: 1097-1101.

19. Brown, A.C., Baigent, S.J., Smith, L.P., Chattoo, J.P., Petherbridge, L.J., Hawes, P., Allday, M.J. and Nair, V. (2006) Interaction of MEQ protein and C-terminal-binding protein is critical for induction of lymphomas by Marek's disease virus. Proc. Natl. Acad. Sci. USA., 103: 1687-1692.

20. Maotani, K., Kanamori, A., Ikuta, K., Ueda, S., Kato, S. and Hirai, K. (1986) Amplification of a tandem direct repeat within inverted repeats of Marek's disease virus DNA 
during serial in vitro passage. J. Virol., 58: 657-660.

21. Shamblin, C.E., Greene, N., Arumugaswami, V., Dienglewicz, R.L. and Parcells, M.S. (2004) Comparative analysis of Marek's disease virus (MDV) glycoprotein-lytic antigen pp38-and transformation antigen MEQ-encoding genes: Association of MEQ mutations with MDVs of high virulence. Vet. Microbiol., 102: 147-167.

22. Lee, S., Takagi, M., Ohashi, K., Sugimoto, C. and Onuma, M. (2000) Difference in the MEQ Gene between oncogenic and attenuated strain of Marek's disease virus serotype 1. J. Vet. Med. Sci., 62(3): 287-292.

23. Frank, F. (2001) Marek's disease: History, actual and future perspectives. Lohmann Inform., 25: 1-5.

24. Balachandran, K., Pazhanivel, N., Vairamuthu, S. and Murali Manohar, B. (2009) Marek's disease and lymphoid leukosis in chicken - a histopathological survey. Tamil Nadu J. Vet. Anim. Sci. 5: 167-170.

25. Hablolvarid, M. (2011) Investigation on incidence of Marek's disease in broiler flocks of some regions in Tehran province, Iran. Arch. Razi Inst., 66(2): 109-114.

26. Musa, I.W., Bisalla, M., Mohammed, B., Sa'idu, L. and Abdu, P.A. (2013) Retrospective and clinical studies of Marek's disease in Zaria, Nigeria. J. Bacteriol. Res., 5(2): 13-21.

27. OIE. (2012) Manual of Diagnostic Tests and Vaccines for Terrestrial Animals. Ch. 2. 3. 13. World Organization for
Animal Health, Paris. p545-554.

28. Murata, S., Hayashi, Y., Kato, A., Isezaki, M., Takasaki, S., Onuma, M., Osa, Y., Asakawa, M., Konnai, S. and Ohashi, K. (2012) Surveillance of Marek's disease virus in migratory and sedentary birds in Hokkaido, Japan. Vet. J., 192(3): 538-540.

29. Van Iddekinge, B.J., Stenzler, L., Schat, K.A., Boerrigter, H. and Koch, G. (1999) Genome analysis of Marek's disease virus strain CVI-988: Effect of cell culture passage on the inverted repeat regions. Avian Dis., 43(2): 182-188.

30. Tian, M.X., Deng, R., Cao, S.J., Wen, X.T., Zou, N.L., Liu, P. and Huang, Y. (2010) Isolation of a field Marek's disease virus with acute oncogenicity from Tibetan chickens in China and sequence analysis of oncogenic genes. In: Proceedings of 2010 First International Conference on Cellular, Molecular Biology, Biophysics and Bioengineering. p259-263.

31. Tian, M., Zhao, Y., Lin, Y., Zou, N., Liu, C., Liu, P., Cao, S., Wen, X. and Huang, Y. (2011) Comparative analysis of oncogenic genes revealed unique evolutionary features of field Marek's disease virus prevalent in recent years in China. Virology, 8: 121.

32. Hassanin, O., Abdallah, F. and EL-Araby, I.E. (2013) Molecular characterization and phylogenetic analysis of Marek's disease virus from clinical cases of Marek's disease in Egypt. Avian Dis., 57: 555-561. 